



\section{U. S. DEPARTMENT OF COMMERCE}

R. P. LAMONT, Secretary

BUREAU OF STANDARDS

GEORGE K. BURGESS, Director

MISCELLANEOUS PUBLICATION No. 113

\section{SIMPLIFICATION OF SIZES AND TERMINOLOGY OF HIGH VOLATILE BITUMINOUS COAL}

(HANDLED OVER DOCKS AT AMERICAN HEAD OF THE GREAT LAKES)

REGIONAL RECOMMENDATION RR1-29

September 26, 1930

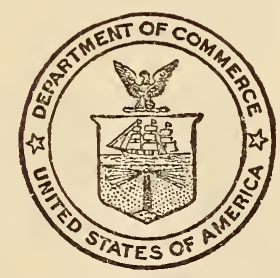

UNITED STATES

GOVERNMENT PRINTING OFFICE

WASHINGTON : 1930

For sale by the Superintendent of Documents, Washington, D. C. - - - - Price E cents 


\section{CONTENTS}

Foreword

List of acceptors.

Regional recommendation

History of project

Standing committee and effective date

Benefits of simplified practice.

The division of simplified practice

Organization and duties of standing committe

Your oooperation

Acceptance form

Request for simplified practice recommendations

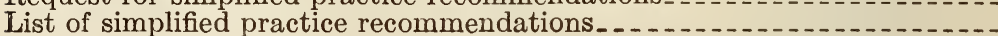




\section{FOREWORD}

The primary function of the division of simplified practice is to assist industrial groups to eliminate unnecessary variety of a given product and thereby reduce manufacturing and distributing costs. In order to secure maximum results, such problems should be handled on a national scale.

Prior to 1929 the division confined its work to projects which from their inception were national in scope. It has, however, become increasingly evident that there is a large field of useful cooperative service in assisting to develop programs applying primarily to only a part of the United States. Obviously some limit must be set up beyond which the division can not be expected to go, and for the present it has been decided to limit this new activity to (a) natural products or commodities, the nature of which varies in different parts of the country, and $(b)$ to programs which hold forth a definite promise of ultimately developing into national recommendations.

There are certain problems, notably in connection with natural products, which can not be effectively handled on a national scale until they have been successfully solved within a limited area or region. A natural rock, not subject to the precise control that governs fabricated materials, exemplifies this class of product. Some aspects of such a problem may always be regional, as, for example, the color in local stone. In certain other aspects, identical characteristics may be found in other regions, and in such cases the regional solutions may prove to be nationally applicable.

A regional program may be the source of a national simplified practice recommendation, but it should never be construed as a local interpretation of a national program. A recommendation applying to a limited geographical area may become nationally known at once, or it can serve to stimulate the development of similar regional projects elsewhere which may eventually be merged into a single national program.

In the case of high volatile bituminous coal handled over the docks at the American head of the Great Lakes, a regional program was successfully developed. Coal interests in other regions are considering similar programs in their own fields. It seems probable that a "common denominator" will materialize which may form the basis of a national program of major importance. The division regards this project as a valuable test case, and has, therefore, cooperated with the coal industry to develop and promulgate Regional Recommendation RR1-29.

Division of Simplified Practice. 



\section{REGIONAL RECOMMENDATION RR1-29}

\section{ACCEPTED BY}

\section{ASSOCIATIONS}

Maher Coal Bureau, The.

National Association of Purchasing Agents (Inc.).

Northwestern Retail Coal Dealers' Association.

Twin City Coal Exchange (Inc.).

Twin City Milk Producers Association

\section{INDIVIDUALS}

American Beet Sugar Co., The, Denver, Colo.

American Hoist \& Derrick Co., St. Paul, Minn.

Archer-Daniels-Midland Co., Minneapolis, Minn.

Armour \& Co., South St. Paul, Minn.

Berwind Fuel Co., Minneapolis, Minn.

Board of Water Commissioners, Flint, Mich.

Burkhardt Milling \& Electric Power Co., Hudson, Wis.

Carleton College, Northfield, Minn.

Carnegie Dock \& Fuel Co., Minneapolis, Minn.

Central West Coal Co., Menominee, Mich.

Chicago, Milwaukee, St. Paul \& Pacific Railroad Co., Chicago, Ill.

City of Watertown, S. Dak.

Clarkson Coal \& Dock Co., The, St. Paul, Minn.

Collis Products Co., St. Paul, Minn.

Commercial Testing \& Engineering Co., Chicago, Ill.

Compo-Board Co., The, Minneapolis, Minn.

Flaxlinum Insulating Co., St. Paul, Minn.

Glen Lake Sanatorium, Oak Terrace, Minn.

Globe Elevator Co., Duluth, Minn.

Great Lakes Coal \& Dock Co., Minneapolis, Minn.

Great Northern Railway Co., St. Paul, Minn.

Hanna Coal \& Dock Co., The M. A., St. Paul. Minn.

Inland Coal \& Dock Co., The, Minneapolis, Minn.

Lake Superior District Power Co., Ashland, Wis.
Loose-Wiles Biscuit Co., Minneapolis, Minn.

Minneapolis, St. Paul \& Sault Ste. Marie Railway Co., Minneapolis, Minn.

Minnesota By-Product Coke Co., St. Paul, Minn.

Moline Implement Co. (plant B), St. Louis Park, Minn.

Monarch Elevator Co., Minneapolis, Minn.

Montgomery Ward \& Co., St. Paul, Minn.

Northern Coal \& Dock Co., The, St. Paul, Minn.

Northern States Power Co., Minneapolis, Minn.

Northwest Paper Co., The, Cloquet, Minn.

Northwestern Fuel Co., St. Paul, Minn.

Okabena Brick \& Tile Co., Okabena, Minn.

Old Ben Coal Corporation, Chicago, Ill.

Otter Tail Power Co., Fergus Falls, Minn.

Peavey Duluth Terminal Co., Duluth, Minn.

Pitt Iron Mining Co., Mountain Iron, Minn.

Pittsburgh \& Ashland Coal \& Dock Co., The, Minneapolis, Minn.

Pittsburgh Coal Co. of Wisconsin, Minneapolis, Minn.

Pursglove Coal \& Dock Co., The, Superior, Wis.

Reiss Coal Co., The C., Sheboygan, Wis.

Star Laundry Co., The, Watertown, S. Dak.

State of Minnesota, St. Paul, Minn.

Swift \& Co., South St. Paul, Minn.

Twin City Brick Co., St. Paul, Minn.

Waldorf Paper Products Co., St. Paul, Minn.

Warner \& Co., W. H., Cleveland, Ohio.

\section{GOVERNMENT}

Department of Labor, Washington, D. C.

Department of the Treasury, Washington, D. C.

Department of War, Washington, D. C.

National Home for Disabled Volunteer Soldiers, Dayton, Ohio. 


\section{ACCEPTANCES "IN PRINCIPLE"}

The following associations, trade journals, technical societies, and organizations approve the general purpose and program of waste elimination and, wherever appropriate, will use their best efforts to further the effectiveness of the program of simplification, of which this recommendation forms a part.

American Artisan magazine.

American Federation of Labor.

American Machinist magazine.

American Society for Testing Materials.

American Standards Association.

Business Week magazine.

Electric Railway Journal.

Electrical World magazine.

Engineers and Engineering magazine.

Engineers Club of Philadelphia.

Factory and Industrial Management magazine.

Hardware Age magazine.

Industrial Distributor and Salesman magazine.

Industrial Engineering magazine.

International Trade Press (Inc.).

Iron Age magazine.

Machinery magazine.
Manufacturing Industries magazine.

Metal Industry magazine.

Metropolitan Life Insurance Co.

Mill Supplies magazine.

Motor World Wholesale magazine.

Power magazine.

Southwestern Purchasing Agent magazine.

Steel magazine.

System magazine.

The American Contractor magazine.

United States Chamber of Commerce:

Department of Manufacture.

Domestic Distribution Depart ment.

Waste Trade Journal.

Welding Engineer Publishing Co.

Wire and Wire Products magazine. 


\title{
SIMPLIFICATION OF SIZES AND TERMINOLOGY OF HIGH VOLATILE BITUMINOUS COAL
}

\author{
(Handled over docks at American head of the Great Lakes)
}

\section{REGIONAL RECOMMENDATION RR1-29}

On April 10, 1929, a general conference of representative dock operators, wholesale and retail dealers, and users of bituminous coal drafted a regional simplified practice recommendation which has since been accepted and approved by the industry for promulgation by the Department of Commerce. This recommendation applies only to high volatile bituminous coal handled over the docks of the American head of the Great Lakes, and distributed mainly in the States of Minnesota, North Dakota, South Dakota, Montana, Iowa, Wisconsin, and Michigan.

1. The following sizes and terminology shall be standard for all the above-described bituminous coal sized at the docks at the American head of the Great Lakes:

Biock_............. Coal passing over a 4-inch screen.

Lump............. Coal passing over a 2-inch screen.

Egg-................. Coal passing through a 4-inch screen, and over a 2 -inch screen.

Stove.............. Coal passing through a 2 -inch screen, and over a $1 \frac{1}{4}$-inch screen.

Nut and slack........- Coal passing through a 2-inch screen.

Screenings......... Coal passing through a $1 \frac{1}{4}$-inch screen.

The above screen sizes refer to round-hole or square-mesh screens.

2. Bar screens having clear openings between bars as listed below shall be standard equivalents for screens listed under 1 .

\begin{tabular}{|c|c|}
\hline $\begin{array}{c}\text { Bar screen } \\
\text { clear } \\
\text { opening }\end{array}$ & $\begin{array}{l}\text { Equivalent } \\
\text { round-hole } \\
\text { screen }\end{array}$ \\
\hline $\begin{array}{c}\text { Inches } \\
25,8 \\
11 / 2 \\
3 / 4\end{array}$ & $\begin{array}{c}\text { Inches } \\
4 \\
2 \\
11 / 4\end{array}$ \\
\hline
\end{tabular}

3. Slotted plate screens having clear widths of slots at the smaller end of the slots as listed below shall be standard equivalents for screens listed under 1.

\begin{tabular}{|c|c|}
\hline $\begin{array}{l}\text { Width of } \\
\text { slot at } \\
\text { small end }\end{array}$ & $\begin{array}{l}\text { Equivalent } \\
\text { round-hole } \\
\text { screen }\end{array}$ \\
\hline $\begin{array}{c}\text { Inches } \\
25 / 8 \\
11 / 2 \\
3 / 4\end{array}$ & $\begin{array}{c}\text { Inches } \\
4 \\
2 \\
11 / 4\end{array}$ \\
\hline
\end{tabular}


These recommendations are effective from May 1, 1929, subject to periodic reconsideration by the standing committee of the industry. Promulgation recommended.

Promulgated.

Approved.

$$
\text { EDWin W. Ely, }
$$
Chief Division of Simplified Practice.

George K. Burgess, Director Bureau of Standards.

R. P. Lamont, Secretary of Commerce. 


\section{HISTORY OF THE PROJECT}

The question of uniform terminology and sizing of high volatile bituminous coal has been considered by various groups in the industry for several years. Owing to the wide variation in local conditions, no large group in any branch of the industry had succeeded in reaching an agreement on this subject. Diversity in terminology and size slowly but steadily increased, particularly during the 15 years immediately preceding the adoption of this recommendation. The effect of this diversity has been serious, in that it tends toward unbalanced output and unbalanced dealers' stocks.

In 1928, representatives of coal dock operators on the Great Lakes took up this problem with the Department of Commerce. After some correspondence, and conferences among representatives of the dock operators, the American Society for Testing Materials, the Bureau of Mines, and the division of simplified practice, a preliminary conference was arranged. In the opinion of the representatives above mentioned, the project fell within the scope of the work of the division of simplified practice, since the primary purpose was a reduction in the existing variety of sizes and terminology.

All of the docks operated by the above-mentioned coal distributors are located at the American head of Lake Superior, at the ports of Duluth, Minn., and Superior, Ashland, and Washburn, Wis. There are no other docks engaged in handling bituminous coal commercially at those ports. There are industrial coal docks located at ports in the Upper Peninsula of Michigan and at Two Harbors, Minn., and one or two commercial docks located in the Upper Peninsula of Michigan, but the latter are small and serve a limited territory.

These dock companies ship their coal into a territory which may be roughly defined as follows: Minnesota, North Dakota, northern half of South Dakota, a few stations in eastern Montana and northern Iowa, northern and central western Wisconsin, and a few towns in the Gogebic iron territory of northwestern Michigan.

According to the Ore and Coal Exchange report No. AC-4, dated January 8, 1929, and covering the lake shipping season of the year 1928, the total movement of coal via the Great Lakes to American ports, was $27,759,438$ net tons.

In approaching this subject, the consensus of the dock operators was that the objects of standardization should be attained in such manner as will provide the consumer with sizes adaptable to the varied uses of dock coal in particular plants; meet competition of coal other than dock coal; and afford to the dock operator a fair return on his product. 


\section{PRELIMINARY CONFERENCE}

(Held at the Maher Coal Bureau, Endicott Building, St. Paul, Minn., January 28, 1929)

A preliminary conference of dock operators was held in St. Paul, Minn., on January 28, 1929, under the auspices of the division of simplified practice. The situation was fully discussed, and an agreement was reached regarding terminology and sizes of coal handled over the docks owned by the companies represented at the conference. J. A. Maher reported that three other dock companies and one large individual coal user, although not represented at this conference, were in sympathy with the project.

In considering the question of equivalent sizes for round-hole screens, bar screens, and slotted-plate screens, it was recognized that there can be no exact equivalents, and that the results will vary with different kinds of coal, width and length of screens, angle of pitch, whether shaker or gravity screens are used, and what volume of coal passes. In arriving at the recommended equivalents, the dock operators based their conclusions on the types of equipment in use on their docks.

It was the sense of the meeting that the recommendations covering terminology and sizes of coal should apply primarily to coal handled over the docks, and distributed to wholesalers, retailers, and users in the States of Wisconsin, Michigan, Iowa, Minnesota, North Dakota, South Dakota, and Montana.

Those present, representing more than 95 per cent of high volatile bituminous coal tonnage handled over the docks, authorized J. A. Maher to request that the division of simplified practice call a general conference before May 1, 1929, for the purpose of presenting these recommendations for action. In view of the fact that such action would directly interest other groups in the coal industry, it was further suggested that representatives of all major groups in the industry, particularly those interested in high volatile bituminous coal, should be invited to attend the general conference. The division issued invitations to such representatives, through national and other associations in the industry, and representatives of manufacturers of coal handling and screening equipment.

Those in attendance at this conference were:

Brandt, F. O., vice president and treasurer, Northern Coal \& Dock Co., St. Paul, Minn.

Clarkson, Worrell, Jr., vice president, Clarkson Coal \& Dock Co., St. Paul, Minn.

Ellis, W. P., northwestern sales agent, Berwind Fuel Co., Chicago, Ill.

Fleming, M. F., vice president, M. A. Hanna Coal \& Dock Co., St. Paul, Minn.

Gonwin, W. H., vice president, sales, Carnegie Dock \& Fuel Co., Minneapolis, Minn.

Gorham, Benjamin, vice president, Northwestern Fuel Co., St. Paul, Minn.

Herrly, P. F., vice president, Pittsburgh \& Ashland Coal \& Dock Co., Minneapolis, Minn.

MACoubrey, J. H., secretary and treasurer, Northwestern Fuel Co., St. Paul, Minn.

Maher, J. A., Maher Coal Bureau, St. Paul, Minn.

Nelson, William, general manager, Great Lakes Coal \& Dock Co., Minneapolis, Minn.

Prinsen, W. A., assistant to president, Inland Coal \& Dock Co., Minneapolis, Minn. 
Roenl, A. K. H., president, Pittsburgh Coal Co. of Wisconsin, Minneapolis, Minn.

DEPARTMENT OF CoMmerce:

LOCK WOOD, R. L., division of simplified practice, Bureau of Standards.

\section{GENERAL CONFERENCE}

\section{(Held at the St. Paul Hotel, St. Paul, Minn., April 10, 1929)}

This conference was held under the auspices of the division of simplified practice of the Department of Commerce at the request of coal-dock operators at the American head of the Great Lakes, for the purpose of acting upon the recommendations formulated by the dock operators.

R. L. Lockwood, of the division, reviewed the development of the project and described the methods and procedure of the division of simplified practice. He then presented the recommendations made by the coal-dock operators as a result of the preliminary conference of January 28, 1929. He also read communications from various individual firms and associations interested in the project and reported favorable opinions of other groups with whom the matter had been discussed.

Copies of the recommendations and agenda for the conference had previously been mailed to individuals, firms, and associations concerned.

It was the sense of the meeting that no attempt should be made to define mine-run or dock-run coal, nor to specify or limit in any way the kind of coal received on the docks. Other features of the program were discussed in detail and Mr. Maher, representing the coaldock operators, explained the methods by which the recommendations had been reached.

Those in attendance at the conference were:

Brandt, F. O., Northern Coal \& Dock Co., St. Paul, Minn.

BrdCe, C. A., Twin City Coal Exchange (Inc.), Minneapolis, Minn.

Clarkson, Worrell, Jr., Clarkson Coal \& Dock Co., St. Paul, Minn.

Daly, M. A., Northern Pacific Railway Co., St. Paul, Minn.

Ellıs, W. P., Berwind Fuel Co., Minneapolis, Minn.

Evans, J. R., Island Creek Coal Co., Cincinnati, Ohio.

Evleth, C. E., Great Northern Railway, St. Paul, Minn.

Fleming, M. E., M. A. Hanna Coal \& Dock Co., St. Paul, Minn.

Freeman, R. S., Great Lakes Coal \& Dock Co., Minneapolis, Minn.

Gilbert, J. S., Monarch Elevator Co., Minneapolis, Minn.

GodwIN, W. H., Carnegie Dock \& Fuel Co., Minneapolis, Minn.

Gorham, Benjamin, North Western Fuel Co., St. Paul, Minn.

Grady, W. A., Old Ben Coal Corporation, Minneapolis, Minn.

Hanson, M. P., C. Reiss Coal Co., Sheboygan, Wis.

Herrly, P. F., Pittsburgh \& Ashland Coal \& Dock Co., Minneapolis, Minn.

Hodck, Stanlex B., Twin City Coal Exchange (Inc.), Minneapolis, Minn.

Jornson, A. E., Chicago, Milwaukee, St. Paul \& Pacific R. R. Co., Chicago, Ill.

LANce, O. C., Northwestern Retail Coal Dealers' Association, Minneapolis, Minn.

LANGtry, W. D., Commercial Testing \& Engineering Co., Chicago, Ill.

Maher, J. A., Maher Coal Bureau, St. Paul, Minn.

Moodr, I. E., 444 Maria, St. Paul, Minn.

Pratt, A. B., Northern States Power Co., Minneapolis, Minn.

Prinsen, W. A., Inland Coal \& Dock Co., Minneapolis, Minn.

RoenL, A. K. H., Pittsburgh Coal Co., Minneapolis, Minn.

Rosebrook, F. D., Chicago \& North Western Railway Co., Chicago, Ill.

Sampson, Charles C., Glen Lake Sanatorium, Oak Terrace, Minn.

Ware, C. P., Peabody Coal Co., Minneapolis, Minn.

Department of Commerce:

LOCK WOD, R. L., division of simplified practice, Bureau of Standards. 


\section{STANDING COMMITTEE AND EFFECTIVE DATE}

The conference approved the appointment of a standing committee to receive all comments and suggestions regarding the recommendation and to hold periodic revision meetings for the purpose of keeping the program abreast of current practice in the industry.

The personnel of the committee is:

Representing Dock Operators:

J. A. Maher, Maher Coal Bureau, St. Paul, Minn. (chairman).

Wayne P. Eluis, northwest sales agent, Berwind Fuel Co.

Representing Distributors:

J. S. Gilbert, manager coal department, Monarch Elevator Co. (also representing Northwestern Retail Coal Dealers' Association).

C. A. BRUCE, secretary, Twin City Coal Exchange. REPRESENTING ÚsERS:

A. B. Pratt, traffic manager, Northern States Power Co.

G. B. Smith, Swift \& Co. (also representing National Association of Purchasing Agents).

The recommendations as set forth herein are effective from May 1,1929 , subject to periodic revision by the standing committee of the industry.

\section{BENEFITS OF SIMPLIFIED PRACTICE}

The program described herein offers the means of eliminating much waste through the cooperation of those concerned in adhering to the approved simplification. The important point is the participation of ALL interests. Those who stay out not only deprive themselves of the economies and increased efficiency inherent in simplification, but prevent the industry as a whole, and its customers, from securing the full measure of these benefits. Some of the specific advantages which can be confidently expected to follow the adoption of simplification are:

\section{TO THE PRODUCER AND MANUFACTURER}

1. Less capital tied up in slow-moving stocks.

2. More economical manufacture due to simplified inspection requirements, longer runs with fewer changes, less idle equipment, less stock to handle, reduced clerical overhead, etc.

3. More permanent employment as contrasted with present seasonal employment.

4. Larger units of production and less special machinery.

5. Prompter delivery.

6. Less chance of error in shipment.

7. Less obsolete material and machinery.

TO THE JOBBER, WHOLESALER, AND RETAILER

1. Increased turnover.

2. Elimination of slow-moving stock:

3. Staple line, easy to buy, quick to sell.

4. Greater concentration of sales efforts on fewer items.

5. Decreased capital invested in stocks and repair parts on hand.

6. Less storage space required.

7. Decreased overhead, handling charges, and clerical work.

\section{TO THE CONSUMER}

1. Better values than otherwise possible.

2. Better service in delivery and repairs.

3. Better quality of product. 
The trade associations and the individuals prominent in this industry have employed their time and thought, together with the services of the division of simplified practive of the Department of Commerce, to lay out a simple and definite plan to reduce waste and thereby give better service at less cost.

\section{THE DIVISION OF SIMPLIFIED PRACTICE}

The origin of the division of simplified practice, its purposes and functions, have been briefly summarized as follows:

The division was established in 1921 by Secretary Herbert Hoover as one of the new units in a broad program of assisting American industries through the Government's cooperation and service rather than through regulations or control. The primary purposes are to have available a centralizing agency for bringing together producers, distributors, and users, and to assist in establishing the recommendations they develop.

Simplified practice may take any form which the industry or business believes will be of service in reducing those extensive wastes which now result from unnecessary variety in shape, size, classification, or any characteristic or process connected with the product. Whatever the form developed, the department stands ready to support all simplifications of practice which will eliminate waste, stabilize business, or extend our national commerce, provided the proposal has the approval of those representing at least 80 per cent of the industry's annual volume.

Any group in any branch-production, distribution, or use-can secure these services upon request.

\section{ORGANIZATION AND DUTIES OF STANDING COMMITTEE}

Nine years' experience has shown that the success of a simplification project depends on four fundamental steps. First, a comprehensive survey of the demand for existing variety; second, a sound and conservative elimination of nonessential items, with proper consideration of the needs of all groups affected; third, enlisting the active support of producers, distributors, and consumers; and, fourth, maintaining interest and adherence by keeping the program abreast of current practice through periodic revision.

The division of simplified practice is convinced that its work in connection with steps one and four is best carried on through committees selected by the industry. These act as liaison agencies and perform the necessary duties which precede and follow a general conference.

At the close of its session the general conference appoints a permanent standing committee, composed of not more than three representatives from each phase of the industry; for example, producers, distributors, and consumers.

The proper functioning of the committee requires that its members be able to attend in person meetings held at some central place. They must also be prepared to devote the necessary time and to accept such assignments and responsibilities as may be found reguisite to the success of the program. 
Because the department in no case assumes the prerogative of taking final action in connection with a simplified practice recommendation, it is essential that there be some avenue through which the industry can be promptly consulted and can, in turn, make known its wishes. This function is best performed by a representative standing committee. For this reason the chairman, in accepting his appointment, places his services and those of his committee at the disposal of the division of simplified practice for the prompt and careful consideration of all questions which may arise when the program is put into actual use.

A committee that quickly and accurately reflects the wishes of the majority of its industry, and through its chairman, promptly disposes of matters referred to it is a practical insurance against any serious difficulty in the adoption of simplified practice.

The standing committee must recognize that the Department of Commerce has no "police powers" to compel the acceptors to adhere strictly to the letter of the recommendation. Unanimous adoption by the general conference indicates a recognition of the benefits inherent in simplification. If this fact is properly emphasized, the acceptors should be equally willing to follow the program in all cases where it is applicable.

While the recommendation is in effect, the standing committee is to receive all information showing departures, and to apply such corrective measures as appear to be in the best interest of all concerned.

The illustration on page 9 shows the important contribution which the standing committee makes to the success of a simplification project.

\section{YOUR COOPERATION}

On page 6 is a brief statement of some of the more obvious and important benefits of simplified practice.

As a producer, distributor, or consumer of some of the commodities which have already been simplified, you are in a position to add impetus to this method of eliminating waste. The first step in that direction is to record your intention to adhere, as closely as circumstances will allow, to one or more of the existing recommendations other than those you have already accepted.

You will, of course, want to examine the schedules before signing. The division of simplified practice will, therefore, furnish a copy of any recommendation which you wish to consider with a view to its adoption. Fill in the form on page 13 and check the recommendations desired from the list appearing on page 14, detach the sheet and mail to division of simplified practice, Bureau of Standards, Washington, D. C. With each recommendation you will receive an acceptance blank on which you can register your intention to adhere to the schedule. There is an acceptance blank for the simplified practice recommendation described herein, on page 11. Publications no longer available through the division can be purchased at a nominal price from the Superintendent of Documents, Government Printing Office, Washington, D. C. (We will furnish price list on request.)

In making your selection, remember that simplified practice applies not only to the things you sell but to the things you buy. On the 


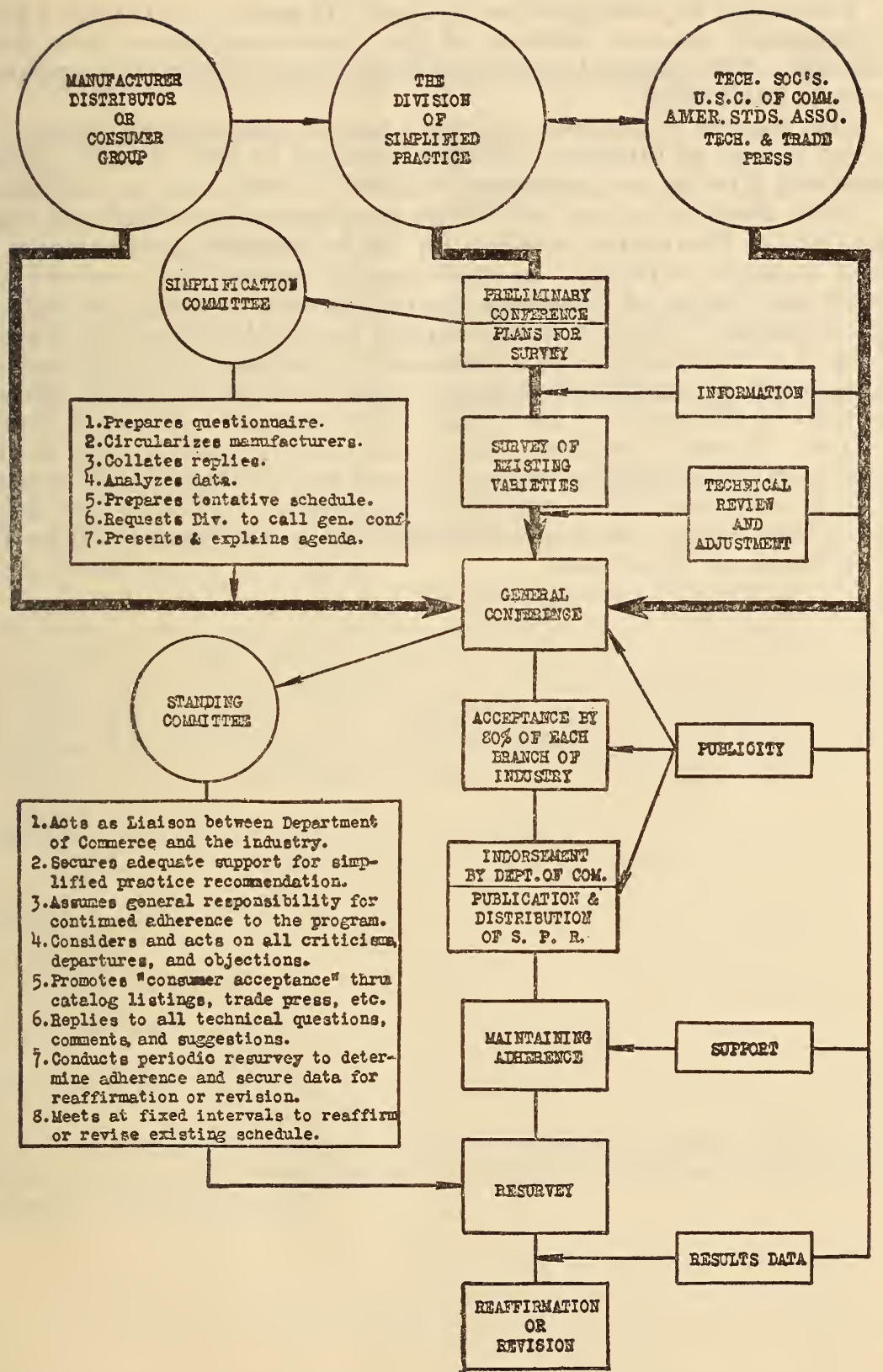

Cooperative development of a simplified practice recommendation 
support accorded by the consumer depends, in a large measure, the success of these waste elimination programs.

The receipt of your signed acceptance will permit the listing of your organization in new editions of the recommendations you have checked. Any proposed revisions will be submitted to you for approval prior to publication.

This support is entirely voluntary and applies to stock items. It is not meant to interfere with the purchase or sale of such special sizes and types as are sometimes required to meet unusual conditions.

Trade associations and individual companies often distribute large numbers of the printed booklets for the information and guidance of their business contacts. In such cases it is possible to extend the scope and degree of adherence by urging each recipient to send in an acceptance. Bear in mind that the practical value of any simplification or standardization is measured by the observance it receives. A number of simplified practice recommendations have already secured an adherence of more than 90 per cent, by volume, of annual output. If each producer, distributor, and consumer will do his part toward discarding nonessentials and specify simplified lines when buying, adherence will approach 100 per cent. Obviously the higher the adherence to each specific simplification the greater will be the benefits to all concerned. 


\section{ACCEPTANCE OF REGIONAL RECOMMENDATION}

[Please sign and return this sheet to Industrial Building, Bureau of Standards, Washington, D. C.]

\section{Division of Simplified Practice, \\ Bureau of Standards,}

$$
\text { Washington, D. C. }
$$

Gentlemen: We, the undersigned, do hereby accept the original draft of Regional Recommendation RR1-29 as our standard practice in $\left\{\begin{array}{l}\text { Dock operation }{ }^{1} \\ \text { Distribution }^{1} \\ \text { Use }^{1}\end{array}\right\}$ of high volatile bituminous coal for a period of one year beginning

is revised, and will use our best effort in securing its general adoption.

$$
\text { Date }
$$
(See reverse side of this sheet.)

To permit intelligent review of the effectiveness of the recommendation every year by an accredited committee of all interests working in cooperation with the Department of Commerce, we will supply all data, upon request, which may be necessary for the development of constructive revision. It is understood that any suggested modifications will be submitted as soon as formulated, and shall not be binding until accepted in form similar to this recommendation.

Signed

(Kindly typewrite or print the following lines)

Title

Company

Street address

City and State

We are members of the following associations or other organizations interested in dock operation or in the distribution and use of high volatile bituminous coal.

\footnotetext{
1 Please designate which group you represent by drawing a line through the other two.
} 


\section{TO THE ACCEPTOR}

In signing this acceptance blank, please bear the following points clearly in mind:

1. Adherence.-The Department of Commerce has no regulatory powers with respect to simplified practice. Instead, simplified practice is based on voluntary cooperation and self-government in industry. To make this specific simplification program operate as a satisfactory example of self-government, it is highly desirable that this recommendation be kept distinct from any plan or method of governmental regulation or control. This simplification will be successful according to the degree to which manufacturers, distributors, and purchasers adhere to its terms and conditions.

2. The industry's responsibility. - This waste-elimination program was developed by the industry on its own initiative. Its success depends wholly on the active cooperation of those concerned. The department oooperates only when requested to do so and only to such extent as appears desirable in order to secure the most beneficial results for all concerned.

3. The acceptor's responsibility.-You are entering into an entirely voluntary arrangement whereby the members of the industry-the distributors and consumers of the product and others concernedhope to secure the benefits inherent in simplified practice. Those responsible for this recommendation realize that instances will occur in which it will be necessary to supply or purchase items not included in the simplified list. The purpose is, however, to limit regular lines of stock items to those described in the schedule, and to place all others in the class of specials. Consumers can make the program a success if they will make a definite effort to confine their purchases to the sizes, etc., specified in this regional recommendation.

4. The department's responsibility.-The function performed by the Department of Commerce is fourfold: First, to provide a neutral agency which will insure adequate consideration of the needs of all interests; second, to secure the widespread adoption and close adherence to the recommendation; third, to add all possible prestige to this waste-elimination plan; and fourth, to supply such assistance and advice in support of this project as past experience with similar programs may suggest. 


\title{
REQUEST FOR SIMPIIFIED PRACTICE RECOMMENDATIONS
}

\begin{abstract}
Date
Division of Simplified Practice,

Bureau of Standards,

Washington, D. C.

Dear Sirs: The undersigned wishes to examine the simplified practice recommendations checked on the reverse side hereof, with a view to accepting them as our standard of practice in the production, distribution, or consumption of the simplified lines.
\end{abstract}

Signed

(Kindly typewrite or print the following lines)

Title

Company -

Street address

City and State 


\section{SIMPLIFIED PRACTICE RECOMMENDATIONS}

No.

1-29. Vitrified paving brick (seventh edition).

2-30. Beds, springs, and mattresses (second edition).

3-28. Metal lath (second edition).

4. Asphalt (first revision).

5. Hotel chinaware.

6. Files and rasps.

7. Rough and smooth face brick; common brick.

8-29. Range boilers and expansion tanks (second odition).

9-28. Woven-wire fencing; woven-wirc fence packages (second edition).

10. Milk bottles and caps (first revision).

11. Bed blankets.

12. Hollow building tile (first revision)

13-28. Structural slate (second edition).

14-28. Roofing slate (second edition).

15. Blackboard slate.

16-29. Lumber (fourth edition)

17-29. Forged tools (third edition).

18. (Now known as Commercial Standard CS22-30.)

19-28. Asbestos paper and asbestos millboard (third edition).

20-28. Steel barrels and drums (second edition).

21. Brass lavatory and sink traps.

22. Paper

23. Plow bolts.

24. Haspital beds.

25. Hot-water storage tanks.

26. Steel reinforcing bars.

27. Cotton duck (first revision).

28-29. Sheet steel (second edition).

29. Eaves trough and conductor pipe.

30-28. Roofing ternes (first revision).

31-30. Loaded paper shot shells (fourth edition).

32. Concrete building units.

33. Cafeteria and restaurant chinaware.

34. Warehouse forms.

35-28. Steel lockers (first revision).

36. Milling cutters.

37-28. Invoice, purchase order, and inquiry forms (second edition).

38. Sand-lime brick.

39. Dining-car chinaware.

40. Hospital chinaware.

41. Insecticides and fungicides (package sizes).

42. Paper grocer's bags.

43-28. Paint and varnish brushes (first revision).

44. Box board thicknesses.

45-28. Grinding wheels (third edition).

46. Tissue paper.

47-28. Cut tacks and small cut nails (second edition).

48. Shovels, spades, and scoops (first revision).

49. Sidewalk, floor, and roof lights.

50. Bank checks, notes, drafts, and similar instruments.

51-29. Chasers for self-opening and adjustable die heads (third edition).

52. (Now known as Commercial Standard CS20-30.)

53. Steel reinforcing spirals.

54. Sterling silver flatware.

55. Tinware, galvanized and japanned ware.

56-28. Carbon brushes and brush shunts (first revision).

\section{4}

No. Item

57. Wrought-iron and wrought-steel pipe, valves, and fittings.

58-28. Classification of iron and steel scrap (first. revision).

59. Rotary-cut lumber stock for wire-bound boxes.

60. Packaging of carriage, machine, and lag bolts.

61. White glazed tile and unglazed ceramic mosaic.

62. Metallic cartridges.

63. Metal spools (for annealing, handling, and shipping wire).

64. (To be assigned.)

65. (To be assigned.)

66. Automobile brake lining.

67. Roller bearings.

68. Metal and fiber flashlight cases.

69. Packaging of razor blades.

70. Salt packages.

71-28. Turnbuckles

72. Solid section steel windows.

73. One-piece porcelain insulators.

74. Hospital and institutional cotton textiles.

75-29. Composition blackboard (second edition). 76. Ash handles.

77. Hickory handles.

78-28. Iron and steel roofing.

79-23. Malleable foundry refractories.

$80-28$. Folding and portable wooden chairs.

81-28. Binder's board.

82-28. Hollow metal doors.

83-28. Kalamein doors.

84-28. Composition books.

85-28. Adhesive plaster.

86-28. Surgical gauze.

87-29. Form dimensions for concrete ribbed floor construction.

88-29. Floor sweeps.

89-28. Coatcd abrasive products.

90-29. Hack-saw blades (second edition).

91-29. Glass containers for preserves, jellies, and apple butter.

92-28. Hard fiber $t w i n e s$ (ply and yarn goods).

93-29. Paper shipping tags.

94. (To be assigned.)

95-28. Skid platforms.

96-28. Ico cake sizes.

97. (To be assigned.)

98-29. Photographic paper.

99-30. Pocket knives.

100-29. Welded chain.

101-29. Metal partitions for toilets and showers.

102. (To be assigned.)

103-29. Industrial truck tires.

104-30. Packaging of flashlight batteries.

105-29. Wheelbarrows.

106-30. Hospital plumbing fixtures.

107. (To be assigned.)

108-29. Dental hypodermic needles.

109-29. Refrigerator ice compartments.

110-29. Soft fiber (jute) twine.

111-30. Color for school furniture.

112-29. Elastic shoe goring.

113-30. Restaurant guest checks.

114-30. No. 1 Kraft paper sealing tape.

115-30. Full disk buffing wheels. 